\title{
Optimization of reversed micellar extraction of chitosanases produced by Bacillus cereus
}

\author{
Ya-Ling Chen ${ }^{\mathrm{a}}$, Chia-Kai Su ${ }^{\mathrm{b}}$, Been-Huang Chiang ${ }^{\mathrm{a}, *}$ \\ a Institute of Food Science and Technology, National Taiwan University, Taipei, Taiwan, ROC \\ ${ }^{\mathrm{b}}$ Department of Leisure, Recreation, and Tourism Management, Southern Taiwan University of Technology, Tainan, Taiwan, ROC
}

Received 4 April 2005; received in revised form 25 September 2005; accepted 26 September 2005

\begin{abstract}
The fermentation broth of Bacillus cereus NTU-FC-4 was precipitated with $70 \%$ acetone to obtain crude enzyme. Chitosanases in the crude enzyme were then extracted by reversed micelles. It was found that proper amount of crude enzyme should be first dissolved in the $50.0 \mathrm{mM}$ phosphate buffer containing $96.0 \mathrm{mM}$ sodium chloride to make a $1.0 \mathrm{mg} / \mathrm{ml}$ protein solution. After adjusting the $\mathrm{pH}$ of the crude enzyme solution to a value of 4.0, the aqueous solution was mixed with an organic solution, the isooctane containing $102.3 \mathrm{mM}$ of the anionic surfactant AOT (sodium 1,2-bis(-2-ethylhexyl) sulfosuccinate). The mixture was shaken in reciprocating shaker bath at $15{ }^{\circ} \mathrm{C}$ for 85 min to solubilize the target enzymes in the reversed micelles formed in the organic phase, thus completed the forward extraction. Then, the reversed micellar phase was separated from the aqueous phase, and allowed to mixed with $50 \mathrm{mM}$ phosphate buffer containing $1.0 \mathrm{M}$ potassium chloride at $\mathrm{pH} 10$. After mixing the two solutions at $40{ }^{\circ} \mathrm{C}$ for $40 \mathrm{~min}$, the target enzymes in the reversed micelles transferred back to the aqueous solution. The processes recovered approximately $70 \%$ of total activity of chitosanases. The purity of the chitosanases was increased to 30 -fold as compared to that of the fermentation broth, and the specific activity of the final product was $60.3 \mathrm{unit} / \mathrm{mg}$.
\end{abstract}

(C) 2005 Elsevier Ltd. All rights reserved.

Keywords: Chitosanases; Bacillus cereus; Reversed micelles; Extraction; Optimization; Enzyme

\section{Introduction}

Chitosan has been recognized as a health promoting food supplement since it possesses antibacterial activity [1-5], hypocholesterolemic activity [6-8], and anti-hypertensive action [9]. However, increasing attention has recently been given to the conversion of chitosan to oligosaccharides. Chitooligomers show interesting biological activities, such as antitumor activity [10-12], immuno-enhancing effects [13], protective effects against infection with some pathogens $[14,15]$, antifungal activity [16], and antimicrobial activity $[3,4]$.

Chitooligosaccharides can be prepared by chemical or enzymatic hydrolysis. However, drawbacks, such as acid corrosion, the need for neutralization after reaction, and low yield of products with degree of polymerization (DP) equal or larger than 6 (DP) limit the practical application of acid

\footnotetext{
* Corresponding author. Tel.: +886 2 23632821; fax: +886 223620849 .

E-mail address: bhchiang@ntu.edu.tw (B.-H. Chiang).
}

hydrolysis. Chitosanases, which represent a class of hydrolytic enzymes, are found in bacteria, fungi, and plants [17]. Among these, bacterial chitosanases appear to be especially useful for the production of chito-oligomers. Bacillus cereus NTU-FC-4, a strain originally isolated from Taiwan soil by Hung [18] was found to be able to produce high amounts of extracellular chitosanases along with a minor amount of chitinase during fermentation. However, a practical method for extraction and purification of these enzymes from the culture broth needs to be established in order to fully explore the industrial applications of these enzymes. The chitosanases from various sources have been purified using the conventional protein purification techniques including ammonium sulfate fractionation, gel filtration, ion-exchange chromatography, and isoelectric focusing [17]. These methods are often used in laboratory practice, but scaling-up of them for commercial production might encounter the problem of limited processing capacity.

Reversed micelles are the aggregates of amphiphilic molecules in an organic solvent. When the reversed micelles are formed with an anionic surfactant, such as AOT, they would display a surface of negative charge surrounding an aqueous 
polar core. Because of the electrostatic interactions, the positively charged proteins could transfer from the aqueous phase to the inner core of the reversed micelles, thus effect a separation [19-25]. Reversed micellar extraction is an attractive separation method for large-scale operation because the process could be carried out using the existing liquid-liquid extraction system in the chemical and biochemical industries. Factors affecting the performance of the reversed micelle system are rather complicated, including the nature and concentration of target protein, $\mathrm{pH}$, and ionic strength of the aqueous phase, extraction temperature, type and concentration of the surfactant, and the processing time [26-28]. Therefore, investigation of the effects of these processing parameters on the performance of reversed micellar extraction often requires tedious experimental works. In this study, all of the processing parameters were considered and pre-tested to screen the factors that had a dominant effect on the process performance. Then, the response surface methodology was used to develop the mathematical functions describing the relationships between these factors and the recovery rate of chitosanases during extraction. Thus, the optimal processing conditions for the purification of chitosanases by the reversed micellar extraction could be established.

\section{Materials and methods}

\subsection{Materials}

Chitin, glucosamine, dioctyl sulfosuccinate sodium salt (AOT), potassium chloride, polyacrylamide, and Coomassie brilliant blue R-250 were purchased from Sigma Chemical Co. (St. Louis, MO). Crab chitosan with 66\% deacetylation was obtained from Ohka Enterprises Co. (Kaohsiung, Taiwan). Other materials used in this study included Soyton and yeast extract (Difco Lab. Sparks, MD), 2,2,4-trimethylpentane (isooctane) (Mallinckrodt Baker Inc., Phillipsburg, NJ), Bio-Rad Dc protein assay kit (Bio-Rad Lab., Hercules, $\mathrm{CA}$ ), and various chemicals of reagent grade.

\subsection{Crude enzyme preparation}

The B. cereus isolated from Taiwan soil and was kindly supplied by Professor Lee of the Department of Agricultural Chemistry of National Taiwan University. The microbe was cultured in a 500-ml glass jar containing $150 \mathrm{ml}$ of the medium composed of $0.3 \%$ colloidal chitin, $0.5 \%$ yeast extract, $0.5 \%$ soyton, $0.1 \%$ potassium dihydrogen phosphate, and $0.5 \%$ magnesium sulfate at $\mathrm{pH}$ 6.24. The jars were incubated in reciprocating shaker at $30^{\circ} \mathrm{C}$ for $48 \mathrm{~h}$. The fermentation broth was centrifuged at $6500 \times g$ for $40 \mathrm{~min}$ at $4{ }^{\circ} \mathrm{C}$, and acetone was added to the supernatant until its concentration reached $70 \%$. The resulting solution was centrifuged at $7000 \mathrm{rpm}$ for $10 \mathrm{~min}$ at $4{ }^{\circ} \mathrm{C}$. The precipitate was dried by lyophilization and used as crude enzyme.

\subsection{Reversed micellar extraction}

The aqueous solutions were prepared by dissolving an appropriate amount of the freeze-dried crude enzyme in $50 \mathrm{mM}$ of sodium phosphate buffers at $\mathrm{pH}$ 3,4 , or 5 . Sodium chloride was added to the aqueous solution to adjust the ionic strength. The organic solution was prepared by dissolving a designated amount of AOT in isooctane. For the forward extraction (i.e. inclusion of enzyme in the reversed micelles), equal volumes (ca. $5 \mathrm{ml}$ ) of the organic solution and aqueous solution were mixed in a centrifugal tube $(15 \mathrm{ml})$ at approximately $200 \mathrm{rpm}$ in a reciprocating shaker bath for various time periods and temperatures. The resulting mixture was then centrifuged at $1000 \times g$ for $10 \mathrm{~min}$ to separate the two phases. The upper layer (reversed micellar solution, the organic phase) was further processed by the subsequent backward extraction (i.e. release of the enzyme from the reversed micelles to the aqueous solution). For backward extraction, the organic solution from forward extraction and equal volume of $50 \mathrm{mM}$ phosphate solution at $\mathrm{pH} 10.0$ containing $1 \mathrm{M} \mathrm{KCl}$ were mixed. The mixture was held at $40{ }^{\circ} \mathrm{C}$ in a water bath for $5 \mathrm{~min}$, shaken at $150 \mathrm{rpm}$ for $40 \mathrm{~min}$, and centrifuged at $1000 \times \mathrm{g}$ for $5 \mathrm{~min}$ to separate the two phases. Samples of aqueous phase were then taken for analysis.

\subsection{The experimental design}

There were six experimental factors that might have affected the recovery of chitosanase activity during reversed micellar extraction. This include protein concentration, $\mathrm{pH}$, and $\mathrm{NaCl}$ concentration in aqueous phase; AOT concentration in the organic phase; and extraction temperature and time. To reduce the number of experimental variables to the level that can be handled practically, initial studies were focused on determining the proper protein concentration $(0.5-5.0 \mathrm{mg} / \mathrm{ml})$, extraction temperature $\left(10-30{ }^{\circ} \mathrm{C}\right)$, and time (15-155 min). These factors were determined using the aqueous solution containing $50.0 \mathrm{mM}$ of $\mathrm{NaCl}$ at $\mathrm{pH} 4$, and the organic solution was $100.0 \mathrm{mM}$ of AOT in isooctane. For studying the proper initial protein concentration, the extractions were carried out at $15{ }^{\circ} \mathrm{C}$ for $85 \mathrm{~min}$. Once these variables were determined, the effects of the other three factors on the recovery of chitosanase activity were further determined experimentally based on a Box-Behnken design [29]. Two sets of experiments were designed and carried out. For the first set of experiment, the $\mathrm{pH}$ were set at 3,4 , or 5 ; AOT concentrations were 50,200 , or $350 \mathrm{mM}$, and sodium chloride concentrations were 50,200 , or $350 \mathrm{mM}$. The $\mathrm{pH}$ for the second set of experiment were 4.0, 4.5, or 5.0; AOT concentrations were 50,100 , or $150 \mathrm{mM}$; and sodium chloride concentrations were 30,90 , or $150 \mathrm{mM}$. The mathematical equations giving the activity recovery as functions of these variables were then developed.

\subsection{Model building and data analysis}

A regression procedure in the SAS package (SAS Institute Inc., Cary, NC) was used to fit the activity recovery data into second-order polynomial equations with interaction terms:

$Y=B_{0}+B_{i} \sum X_{i}+B_{i i} \sum X_{i}^{2}+B_{i j} \sum X_{i j} \quad(i \neq j)$

where $Y$ is the dependent variable, $B_{0}, B_{i}, B_{i i}$, and $B_{i j}$ regression coefficients of the model and $X_{i}$ are magnitudes of the selected critical variables. An $F$-test for lack of fit was used to determine whether the regression models adequately fit the experimental data. Once the regression models were developed, non-linear programming techniques were used to search the maximum recovery of chitosanase activity. A commercial linear and non-linear programming package "AMPL" (The Scientific Press, San Francisco, CA) [30] was used to search for the optimal conditions.

\subsection{Analytical methods}

The protein concentration was determined by the modified Lowry method using Bio-Rad protein Dc protein assay kit [31]. SDS-polyacrylamide gel electrophoresis using $10 \%$ acrylamide was performed and stained by Coomassie blue R-250 [32]. The sheets were destained with acetic acid/methanol/water solution (1/3/6, v/v/v). A pre-stained protein standard (SeeBlue Plus2, Invitrogen Co., Carlsbad, CA) was used during SDS-PAGE for determining the molecular weights of the separated proteins. Chitosanase activity was determined by measuring the reducing sugar produced from chitosan. Chitosan was dissolved in the $0.2 \mathrm{M}$ acetate buffer at $\mathrm{pH} 5$ to make a $1 \%(\mathrm{w} / \mathrm{v})$ chitosan solution. A mixture consisting of $1 \mathrm{ml}$ of $1 \%$ chitosan solution, $3.5 \mathrm{ml}$ of $0.2 \mathrm{M}$ acetic acid solutions, and $0.5 \mathrm{ml}$ of enzyme solution was then prepared and incubated at $45^{\circ} \mathrm{C}$ for $30 \mathrm{~min}$, then boiled for $15 \mathrm{~min}$ to stop the reaction. A portion of the mixture $(0.5 \mathrm{ml})$ was mixed with $1.8 \mathrm{ml}$ of water and $2 \mathrm{ml}$ of alkaline ferri-cyanide solution, and the reducing sugar produced was measured colorimetrically [33] using a standard curve constructed by pure compound of glucosamine. One enzyme unit was defined as the amount of enzyme that hydrolyzed $1 \%$ chitosan solution to yield $1 \mu \mathrm{mol}$ of reducing sugar per minute at $45^{\circ} \mathrm{C}$. 


\section{Results and discussion}

\subsection{Preparation of the crude enzyme}

After incubating the B. cereus at $30{ }^{\circ} \mathrm{C}$ for 2 days, the culture broth was centrifuged, and the crude enzyme was precipitated by acetone. The above procedure recovered $86 \%$ of the total chitosanase activity from the culture broth, and raised its specific activity from 2.0 to $24.7 \mathrm{unit} / \mathrm{mg}$ protein, a 12 -fold increase. Then, reversed micellar extraction was used to further purify the chitosanases.

\subsection{Effects of protein concentration, extraction temperature and time}

Fig. 1 shows the effect of initial protein concentration on the extraction performance. It was found that the maximum amount of chitosanase activity could be recovered at the initial protein concentration of $1 \mathrm{mg} / \mathrm{ml}$. When the initial protein concentration was higher than $1 \mathrm{mg} / \mathrm{ml}$, the recovery of chitosanase activity decreased. It was suspected that the interactions between protein molecules might interfere the extraction performance when the protein concentration was too high. Therefore, the initial crude enzyme concentration was fixed at $1.0 \mathrm{mg} / \mathrm{ml}$ for the subsequent studies.

The temperature and time are two important physical parameters involved in the reversed micellar extraction. Since these two physical parameters, theoretically, had less interactions with the other chemical parameters, including $\mathrm{pH}, \mathrm{NaCl}$ concentration, and AOT concentration, it was decided to determine them first in order to minimize the number of independent variables in this study. The effects of extraction time and temperature on the extraction performance were investigated and the results are shown in Fig. 2. In general, the extraction conducted at $15^{\circ} \mathrm{C}$ accomplished the highest

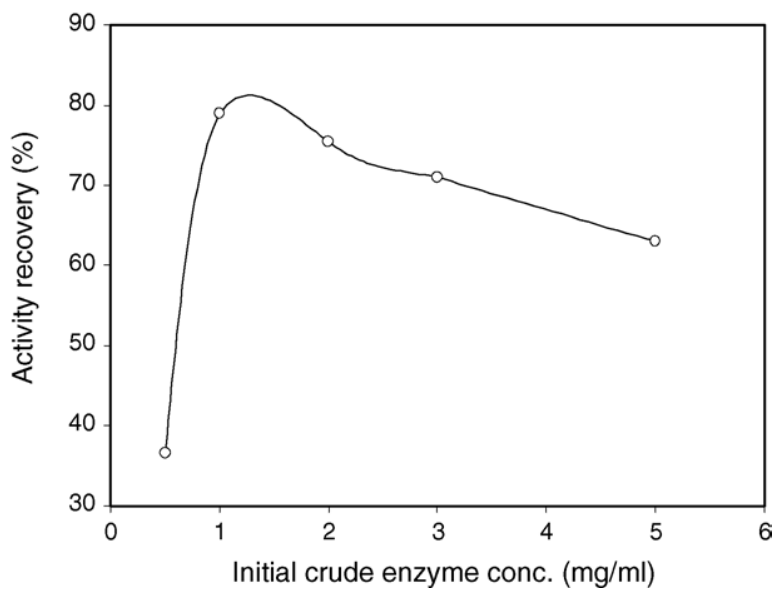

Fig. 1. Effect of initial protein concentration in the aqueous phase on the recovery of chitosanase activity during reversed micellar extraction. The forward extraction was carried out at $15^{\circ} \mathrm{C}$ for $85 \mathrm{~min}$. The aqueous phase was $150 \mathrm{mM}$ phosphate buffer at $\mathrm{pH} 4$ and the $\mathrm{NaCl}$ concentration was $150 \mathrm{mM}$. The AOT concentration in the organic phase was $100 \mathrm{mM}$. The backward extraction was carried out at $40{ }^{\circ} \mathrm{C}$ for 40 min using $50 \mathrm{mM}$ phosphate buffer containing $1 \mathrm{M} \mathrm{KCl}$ at $\mathrm{pH} 10$ as the aqueous phase.

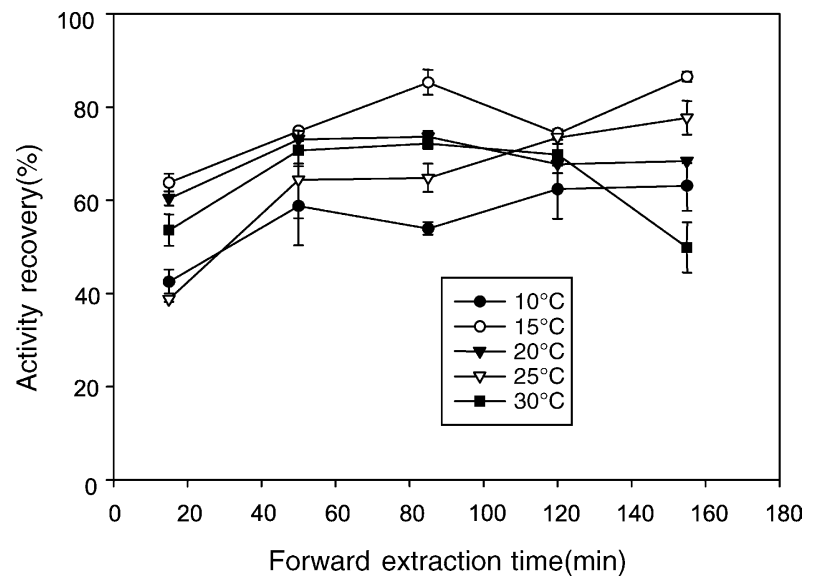

Fig. 2. Effects of temperature and time on the recovery of chitosanase activity. During forward extraction, the aqueous phase was $150 \mathrm{mM}$ phosphate buffer at $\mathrm{pH} 4$ and contained $50 \mathrm{mM} \mathrm{NaCl}$. The AOT concentration in the organic phase was $100 \mathrm{mM}$. The backward extraction was carried out at $40{ }^{\circ} \mathrm{C}$ for $40 \mathrm{~min}$ using $50 \mathrm{mM}$ phosphate buffer containing $1 \mathrm{M} \mathrm{KCl}$ at $\mathrm{pH} 10$ as the aqueous phase.

chitosanase activity recovery among the different temperatures tested ranging from 10 to $30{ }^{\circ} \mathrm{C}$. It appeared that temperature below $15{ }^{\circ} \mathrm{C}$ might be too low to facilitate mass transfer. A higher temperature, on the other hand, might have loosened the structure of the reversed micelles, thus offering less protection for the enzyme when it passed through the aqueous/organic inter-phase to enter the micelles. It was noticed that there was a dramatic decrease in the recovery of the chitosanase activity for the extraction conducted at high temperature (i.e. $30{ }^{\circ} \mathrm{C}$ ) for a long time (i.e. $160 \mathrm{~min}$ ). In general, increasing the extraction time would increase the chance for the enzyme to contact the organic solvent and being inactivated. Dekker et al. [34] found that the maximum amount of protein that could be solubilized in the reversed micellar phase would be a function of temperature. Chou and Chiang [23] also found that lowering extraction temperature facilitated the extraction of lysozyme into the micellar phase. However, the mass transfer rate of the protein would decrease with decreasing temperature, and therefore, the extraction time should be increased to compensate for the reduced mass transfer rate. From another viewpoint, too long of an extraction time might have increased the chance for the proteins to contact with the organic solvent, leading to protein denaturation and affecting the performance. Based on the results of this study, the forward extraction time was fixed at $85 \mathrm{~min}$ and the temperature was at $15^{\circ} \mathrm{C}$ for the subsequent experiments.

\subsection{Optimization of extraction conditions}

There were three parameters that needed to be investigated to search for the optimum process conditions to recover chitosanase during reversed micellar extraction. This includes $\mathrm{pH}\left(X_{1}\right)$, AOT concentration of the organic phase $\left(X_{2}\right)$, and $\mathrm{NaCl}$ concentration of the aqueous phase $\left(X_{3}\right)$. Table 1 shows the extraction conditions and results of the first experimental set for studying the effects of these variables on the recovery of 
Table 1

Recovery of chitosanase activity from crude enzyme by reversed micellar extraction based on Box-Behnken design

\begin{tabular}{rlrrr}
\hline No. & $\mathrm{pH}\left(X_{1}\right)$ & $\begin{array}{c}{[\mathrm{AOT}]} \\
(\mathrm{mM})\end{array}$ & $\begin{array}{c}{\left[X_{2}\right)} \\
(\mathrm{maCl})\end{array}$ & Recovery $(\%)$ \\
\hline 1 & 3 & 50 & 200 & 3.98 \\
2 & 3 & 200 & 50 & 2.14 \\
3 & 3 & 200 & 350 & 0.68 \\
4 & 3 & 350 & 200 & 3.62 \\
5 & 3 & 350 & 200 & 5.19 \\
6 & 4 & 50 & 50 & 68.75 \\
7 & 4 & 50 & 50 & 62.53 \\
8 & 4 & 50 & 350 & 2.30 \\
9 & 4 & 200 & 200 & 50.15 \\
10 & 4 & 200 & 200 & 49.57 \\
11 & 4 & 200 & 200 & 52.45 \\
12 & 4 & 350 & 50 & 47.61 \\
13 & 4 & 350 & 350 & 3.10 \\
14 & 5 & 50 & 200 & 28.82 \\
15 & 5 & 200 & 50 & 50.13 \\
16 & 5 & 200 & 50 & 55.84 \\
17 & 5 & 200 & 350 & 3.60 \\
18 & 5 & 350 & & 1.66 \\
\hline
\end{tabular}

chitosanase activity based on a Box-Behnken design [29]. A second-degree polynomial model based on regression analysis was then developed showing the recovery of chitosanase activity $\left(Y_{1}\right)$ as the function of the processing variables:

$$
\begin{aligned}
Y_{1}= & -434.852+221.847 X_{1}+0.034 X_{2}+0.262 X_{3} \\
& -24.612 X_{1}^{2}+0.005 X_{1} X_{2}-0.0003 X_{2}^{2}-0.066 X_{3} X_{1} \\
& +0.0003 X_{3} X_{2}-0.0005 X_{3}^{2}
\end{aligned}
$$

The coefficient of determination $\left(R^{2}\right)$ of the model for activity recovery was 0.95 , indicating a generally good fit of the model. The highest possible recovery of chitosanase activity resulting from the first experimental set was estimated to be $66.4 \%$ using the non-linear programming technique, which was obtained by carrying out the extraction at $\mathrm{pH} 4.5$, sodium chloride concentration of $112.4 \mathrm{mM}$, and AOT concentration of $50.0 \mathrm{mM}$.

The $\mathrm{pH}$ of the aqueous phase is an important parameter affecting reversed micellar extraction [35-37]. For the AOT/ isooctane reversed micellar system, significant transfer of protein occurs when the $\mathrm{pH}$ values are below the isoelectric point $(\mathrm{p} I)$ of protein. The $\mathrm{p} I \mathrm{~s}$ of chitosanases secreted from $B$. cereus NTU-FC-4 are about 6.8-7.2 [18]; therefore, the enzymes could transfer into reversed micellar phase at $\mathrm{pH}$ below 6.8. Eq. (2) indicates that the recovery of chitosanase activity increases with increasing $\mathrm{pH}$. It is known that the enzymes are more positively charged at a lower $\mathrm{pH}$, rendering a stronger interaction between cationic proteins with anionic AOT head, and thus facilitating the extraction. However, the size of the protein molecule also influences its uptakes by the reversed micelles. Larger proteins appear to be more difficult to transfer into reversed micelles, and a $\mathrm{pH}$ much lower than its isoelectric point is needed for an efficient transfer. The small proteins, on the other hand, can be transferred at a $\mathrm{pH}$ very close to its isoelectric point $[38,39]$. The molecular weights of the chitosanases produced by $B$. cereus NTU-FC-4 are around 47$66 \mathrm{kDa}$ [18], a medium size protein. Considering both the electrostatic interaction and the size of the enzymes, the second set of the experiment was carried out with increasing $\mathrm{pH}$ from 4 to 5 .

The concentration of surfactant affects the size of reversed micelles [39]. With increasing AOT concentration, the size of reversed micelles increases. Micelle size in the aqueous phase, however, remains constant once the concentration of the surfactant exceeds the critical micelle concentration [40]. Therefore, the amount of extracted protein in the reverse micellar phase (organic phase) also increased with increasing AOT concentration, and reached a maximum until certain AOT concentration [41]. Results from the first experimental set suggested that a proper AOT concentration should be around $100 \mathrm{mM}$. Therefore, it was decided that the AOT concentrations for the second set of experiment were in the range of 50 $150 \mathrm{mM}$.

Sodium chloride in the aqueous phase was to provide the proper ionic strength for the extraction. Addition of a proper amount of salt into the aqueous phase is desirable for the extraction of a large amount of protein into the reverse micellar phase [41]. However, when the ionic strength is too high, the electrostatic screening effect might reduce the interaction between protein and surfactant molecules [42]. High ionic strength also reduces the electrostatic repulsion between the surfactant head groups, resulting in a decrease in the size of the reverse micelles, thus decreases the extent of protein being solubilized to the reverse micellar phase $[40,43]$. Results of the first experimental set revealed that $\mathrm{NaCl}$ concentration should be around $50 \mathrm{mM}$ for the extraction, and Eq. (2) suggested that further increasing the $\mathrm{NaCl}$ concentration might be helpful for increasing the

Table 2

Recovery of chitosanase activity from crude enzyme by reversed micellar extraction based on Box-Behnken design and the specific activity of the extract

\begin{tabular}{rlccll}
\hline No. & $\mathrm{pH}\left(X_{1}\right)$ & $\begin{array}{l}{[\mathrm{AOT}]} \\
(\mathrm{mM})\end{array}$ & $\begin{array}{l}{\left[X_{2}\right)} \\
(\mathrm{mM})\end{array}$ & $\begin{array}{l}\text { Recovery } \\
(\%)\end{array}$ & $\begin{array}{l}\text { Specific activity } \\
\text { (unit/mg) }\end{array}$ \\
\hline 1 & 4 & 50 & 90 & 77.5 & 46.8 \\
2 & 4 & 100 & 30 & 67.8 & 67.4 \\
3 & 4 & 100 & 150 & 72.7 & 55.0 \\
4 & 4 & 150 & 90 & 77.1 & 54.0 \\
5 & 4 & 150 & 90 & 84.1 & 60.7 \\
6 & 4.5 & 50 & 30 & 58.5 & 48.9 \\
7 & 4.5 & 50 & 30 & 59.7 & 47.1 \\
8 & 4.5 & 50 & 150 & 49.2 & 35.4 \\
9 & 4.5 & 100 & 90 & 63.8 & 46.9 \\
10 & 4.5 & 100 & 90 & 64.0 & 47.2 \\
11 & 4.5 & 100 & 90 & 65.6 & 45.6 \\
12 & 4.5 & 150 & 30 & 58.9 & 36.1 \\
13 & 4.5 & 150 & 150 & 44.4 & 32.6 \\
14 & 5 & 50 & 90 & 45.6 & 47.5 \\
15 & 5 & 100 & 30 & 64.5 & 48.5 \\
16 & 5 & 100 & 30 & 62.0 & 45.7 \\
17 & 5 & 100 & 150 & 41.9 & 46.5 \\
18 & 5 & 150 & 150 & 32.1 & 29.1 \\
\hline
\end{tabular}


Table 3

Specific activity and recovery of chitosanase activity during purification processes

\begin{tabular}{lllc}
\hline Purification step & $\begin{array}{l}\text { Activity } \\
\text { recovery }(\%)\end{array}$ & $\begin{array}{l}\text { Specific activity } \\
\text { (unit/mg protein) }\end{array}$ & $\begin{array}{l}\text { Purification } \\
\text { (fold) }\end{array}$ \\
\hline $\begin{array}{l}\text { Centrifugation } \\
\begin{array}{l}\text { Precipitation by } \\
70 \%(v / v) \text { acetone }\end{array}\end{array}$ & 100 & 2.0 & 1 \\
$\begin{array}{l}\text { Reversed micellar } \\
\text { extraction }\end{array}$ & 65.9 & 24.7 & 12.3 \\
\hline
\end{tabular}

chitosanase recovery during reversed micellar extraction. Therefore, the salt concentrations ranged from 30 to $150 \mathrm{mM}$ were investigated for the second set of experiment.

Table 2 shows the effects of the three variables discussed above on the recovery and specific activity of chitosanase $\left(Y_{2}\right)$ based on a Box-Behnken design. Again, a second-degree polynomial model based on regression analysis was developed
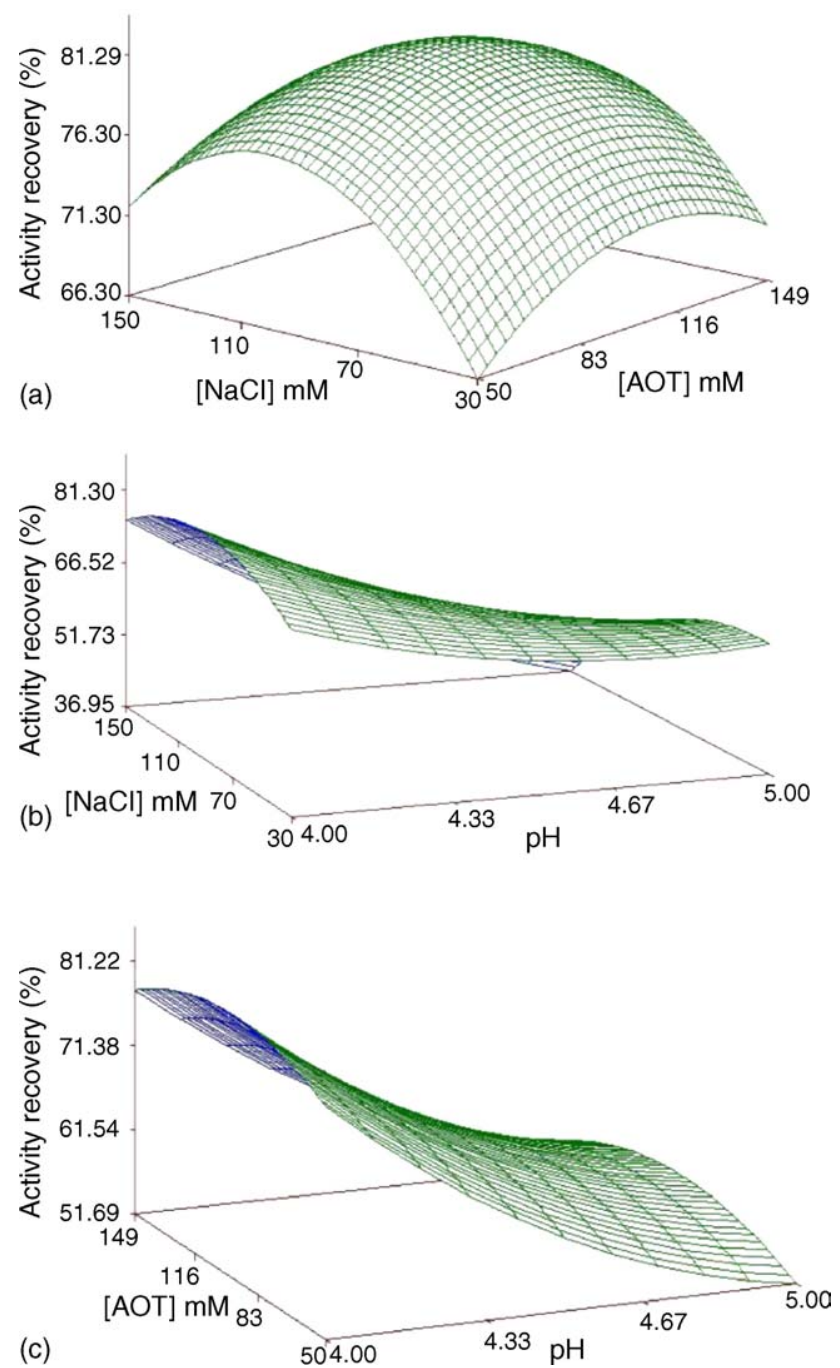

Fig. 3. Effects of process variables on the recovery of chitosanase activity during reversed micellar extraction. (a) $\mathrm{pH}$ of the aqueous phase was 4; (b) AOT concentration was $102.4 \mathrm{mM}$; (c) sodium chloride concentration was $96 \mathrm{mM}$.
Table 4

Effect of $\mathrm{NaCl}$ and AOT concentrations on the activity recovery of chitosanase at $\mathrm{pH} 3.5$

\begin{tabular}{lc}
\hline Treatment & Activity recovery (\%) \\
\hline $30 \mathrm{mM} \mathrm{NaCl}, 100 \mathrm{mM}$ AOT & 1.2 \\
$90 \mathrm{mM} \mathrm{NaCl}, 50 \mathrm{mM}$ AOT & 33.8 \\
$90 \mathrm{mM} \mathrm{NaCl}, 150 \mathrm{mM}$ AOT & 71.7 \\
$150 \mathrm{mM} \mathrm{NaCl}, 100 \mathrm{mM}$ AOT & 54.3 \\
\hline
\end{tabular}

showing the recovery of chitosanase activity as the function of the three processing variables:

$$
\begin{aligned}
Y_{2}= & 422.930-168.097 X_{1}+0.288 X_{2}+1.393 X_{3} \\
& +18.160 X_{1}^{2}+0.0195 X_{1} X_{2}-0.002 X_{2}^{2}-0.237 X_{3} X_{1} \\
& -0.0004 X_{3} X_{2}-0.002 X_{3}^{2}
\end{aligned}
$$

The coefficient of determination $\left(R^{2}\right)$ of this equation was 0.95 , indicating a generally good fit of the model. The highest possible rate of chitosanase activity recovery was estimated to be $81.3 \%$ using non-linear programming technique, which was obtained by operating the reversed micellar extraction at $\mathrm{pH}$ 4.0, AOT concentration of $102.4 \mathrm{mM}$, and sodium chloride concentration of $96.0 \mathrm{mM}$. A regression equation for the specific activity $\left(Y_{3}\right)$ as the function of the three processing variables was also established:

$$
\begin{aligned}
Y_{3}= & 561.859-243.508 X_{1}+2.008 X_{2}-0.637 X_{3} \\
& +27.924 X_{1}^{2}-0.320 X_{1} X_{2}-0.004 X_{2}^{2}+0.103 X_{3} X_{1} \\
& +0.0008 X_{3} X_{2}+0.0002 X_{3}^{2}
\end{aligned}
$$

The $R^{2}$ of this model was 0.98 . It was estimated that the specific activity of the product extracted at $\mathrm{pH} 4.0$, AOT concentration of $102.4 \mathrm{mM}$, and sodium chloride concentration of $96.0 \mathrm{mM}$ was $60.3 \mathrm{unit} / \mathrm{mg}$ protein, a 2.4-fold increase from the acetone precipitate. Changes of activity recovery and specific activity of chitosanases during acetone precipitation

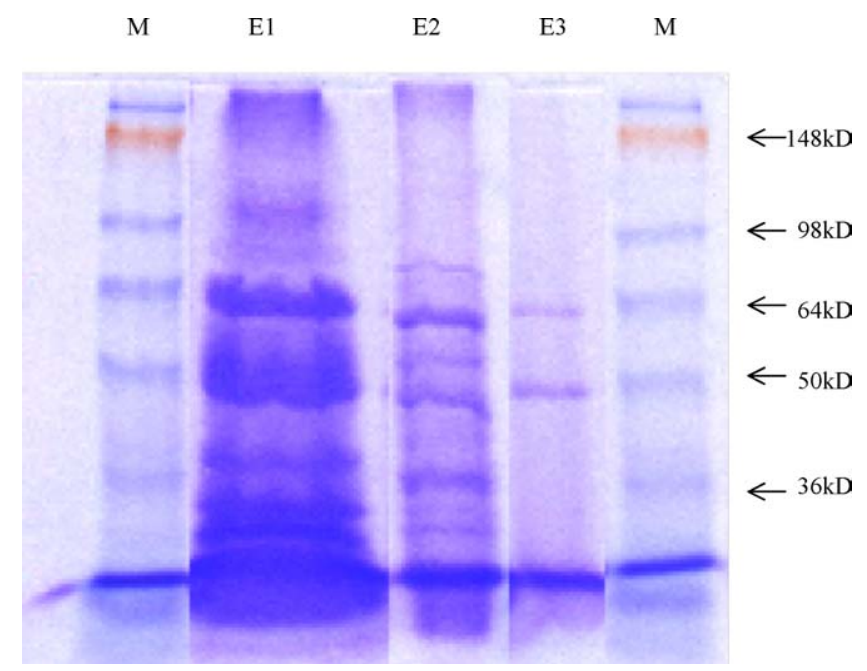

Fig. 4. SDS-PAGE of chitosanases. M, mixture of standard protein with various molecular weights; E1, the fermentation broth; E2, the acetone precipitate; E3, the chitosanases extracted by reversed micelles. 
and reversed micellar extraction processes are summarized in Table 3.

By fixing one of the three variables of the operation condition for obtaining the highest recovery, the effect of the rest of two variables on the recovery of chitosanase are illustrated by Fig. 3. As expected, when the $\mathrm{pH}$ was fixed at the value of 4 the highest recovery of chitosanases was found at an AOT concentration of $102.4 \mathrm{mM}$ and sodium chloride concentration of $96 \mathrm{mM}$ (Fig. 3(a)). However, when fixing either the AOT concentration at $102.4 \mathrm{mM}$ or the sodium chloride concentration at $96.0 \mathrm{mM}$ Fig. 3(b) and (c), it appeared that further decreases of $\mathrm{pH}$ might increase the chitosanases activity recovery. Hence, a separate experiment was conducted at a lower $\mathrm{pH}$ of 3.5 and various AOT and sodium chloride concentrations (Table 4). Results indicated that the chitosanases activity recoveries obtained at all of the tested conditions were lower than those obtained at $\mathrm{pH} 4$ (compared to the data shown in Table 2). It was suspected that the aqueous phase with $\mathrm{pH}$ lower than 4 might damage the chitosanases activity during extraction.

\subsection{Changes of protein profile during purification process}

Electrophoretic patterns of fermentation broth, acetone precipitate, and the extracts of reversed micelles are shown in Fig. 4. After reversed micellar extraction, the extract consisted of two major proteins with molecular weights around 64 and $50 \mathrm{kDa}$, respectively. Hung [18] used the colloidal chitosan to adsorb the chitosanases from the acetone precipitate, and purified the enzymes using preparative electrophoresis, and found that two kinds of chitosanases existed in the acetone precipitate, namely Chitosanase I and Chitosanase II. The Chitosanase I had two subunits with molecular weights 56 and $66 \mathrm{kDa}$, and Chitosanase II had a molecular weight of $47 \mathrm{kDa}$. It appeared that the reversed micelles removed some nonchitosanase proteins as well as a chitosanase subunit, and yielded a more purified chitosanase product.

\section{Conclusion}

This research demonstrated that separation of chitosanases from the fermentation broth of $B$. cereus NTU-FC-4 could be carried out by two steps. The first step was to fractionate crude enzyme by $70 \%$ acetone precipitation, and the second step was to purify the chitosanases from crude enzyme using reversed micellar extraction. When the reversed micellar extraction was operated at an optimal condition, the complete procedure, including acetone precipitation and reversed micellar extraction, recovered approximately $70 \%$ of chitosanase activity from the fermentation broth. The specific activity increased 30-fold.

Extraction of chitosanase directly from fermentation broth by reversed micelles without organic solvent precipitation would be another consideration. However, there will be more non-target contaminants that might interfere with the partition behavior of target protein. Besides, the cell debris, being larger molecules, would possibly be precipitated with surfactant in the interface layer [44]. In spite of these possible shortcomings, future research is needed to investigate the possibility of applying the technique of reversed micellar extraction to the fermentation broth directly. Nevertheless, the present results give evidence of the potential of AOT reversed micelles for the extraction and purification of chitosanases. However, in order to establish commercially viable processes, further work will be necessary to study the scale-up engineering and the recycling of the organic solution after completed extractions.

\section{References}

[1] Allan GR, Hadwiger LA. The fungicidal effect of chitosan on fungi of varying cell wall composition. Exp Mycol 1979;3:285-7.

[2] Walker-Simmons M, Hadwiger L, Ryan CA. Chitosans and pectic polysaccharides both induce the accumulation of the antifungal phytoalexin posatin in pea pods and antinutrient proteinase inhibitors in tomato leaves. Biochem Biophys Res Commun 1989;110:194-9.

[3] Hirano S, Nagao N. Effect of chitosan, pectic acid, lysozyme, and chitinase on the growth of several phytopathogens. Agric Biol Chem 1989;53:3065-6.

[4] Hadwiger LA, Beckman JM. Chitosan as a component of pea-Fusarium solani interaction. Plant Physiol 1980;66:205-11.

[5] Maezaki Y, Tsuji K, Nakagawa Y, Kawai Y, Akimoto M, Tsugita T, et al. Hypocholesterolemic effect of chitosan in adult males. Biosci Biotechnol Biochem 1993;57:1439-44.

[6] Hirano S, Itakura C, Seino H, Akiyama Y, Nonaka I, Kanbara N, et al. Chitosan as an ingredient for domestic animal feeds. J Agric Food Chem 1990;38:1214-7.

[7] Sugano M, Watanabe S, Kishi A, Izume M, Ohtakara A. Hypocholesterolemic action of chitosans with different viscosity in rats. Lipids 1988;23: $187-91$.

[8] Sugano M, Fujikawa T, Hiratsuji Y, Nakashima K, Fukuda N, Hasegawa Y. A novel use of chitosan as a hypocholesterolemic agent in rats. Am J Clin Nutr 1980;33:787-93.

[9] Okuda H, Kato H, Tsujita T. Antihypertensive and antihyperlipemic actions of chitosan. Korean J Chitin Chitosan 1997;2:49-59.

[10] Suzuki K, Mikami T, Okawa Y, Tokoro A, Suzuki S, Suzuki M. Antitumor effect of hexa- $N$-acetylchitohexaose and chitohexaose. Carbohydr Res 1986;151:403-8.

[11] Tsukada K, Matsumoto T, Aizawa K, Tokoro A, Naruse R, Suzuki S, et al. Antimetastatic and growth-inhibitory effects of $\mathrm{N}$-acetylchitohexaose in mice bearing Lewis lung carcinoma. Jpn J Cancer Res 1990;81:259-65.

[12] Suzuki S. Studies on biological effects of water soluble lower homologous oligosaccharides of chitin and chitosan. Fragrance J 1996;15:61-8.

[13] Tokoro A, Tatewaki N, Suzuki K, Mikami T, Suzuki S, Suzuki M. Growthinhibitory effect of hexa- $\mathrm{N}$-acetylchitohexaose and chitohexaose against Meth-a solid tumor. Chem Pharm Bull 1988;36:784-90.

[14] Yamada A, Shibbuya N, Kodama O, Akatsuka T. Induction of phytoalexin formation in suspension-cultured rice cells by $N$-acetyl chitooligosaccharides. Biosci Biotechnol Biochem 1993;57:405-9.

[15] Tokoro A, Kobayashi M, Tatekawa N, Suzuki K, Okawa Y, Mikami T, et al. Protective effect of $\mathrm{N}$-acetyl chitohexaose on Listeria monocytogenes infection in mice. Microbiol Immunol 1989;33:357-67.

[16] Kendra DF, Christian D, Hadwiger LA. Chitosan oligomers from Fusarium solani/pea interactions, chitinase/ $\beta$-glucanase digestion of sporelings and from fungal wall chitin activity inhibit fungal growth and enhance disease resistance. Physiol Mol Plant Pathol 1989;35:215-30.

[17] Somashekar D, Joseph R. Chitosanase-properties and applications: a review. Bioresource Technol 1996;55:35-45.

[18] Hung CC. Studies on chitinase and chitosanase from Bacillus cereus NTU-FC-4. Master thesis. Taipei, Taiwan: Department of Agricultural Chemistry, National Taiwan University; 1994.

[19] Huang SY, Lee YC. Separation and purification of horseradish peroxidase from Armoracia rusticana root using reversed micellar extraction. Bioseparation 1994;4:1-5. 
[20] Liu D, Ma J, Cheng H, Zhao Z. Solubilization behavior of mixed reverse micelles: effect of surfactant component, electrolyte concentration and solvent. Colloids Surf A Physicochem Eng Aspects 1998;143: 59-68.

[21] Nishiki T, Muto A, Kataoka T, Kato D. Back extraction of proteins from reversed micellar to aqueous phase: partitioning behaviour and enrichment. Chem Eng J 1995;59:297-301.

[22] Naoe K, Ura O, Hattori M, Kawagoe M, Imai M. Protein extraction using non-ionic reverse micelles of Span 60. Biochem Eng J 1998;2:113-9.

[23] Chou ST, Chiang BH. Reversed micellar extraction of hen egg lysozyme. J Food Sci 1998;63:399-402.

[24] Shah C, Sellappan S, Madamwr D. Entrapment of enzyme in waterrestricted microenvironment-amyloglucosidase in reverse micelles. Process Biochem 2000;35:971-5.

[25] Su CK, Chiang BH. Extraction of immunoglobulin-G from colostral whey by reverse micelles. J Dairy Sci 2003;86:1639-45.

[26] Dekker M, Riet KV, Weijers SR. Enzyme recovery by liquid-liquid extraction using reversed micelles. Chem Eng J 1989;178:217-26.

[27] Dekker M, Van't Riet K, Bijsterbosch BH, Fijneman P, Hilhorst R. Modeling and optimization of the reversed micellar extraction of $\alpha$ amylase. AIChE J 1989;35:321-4.

[28] Goklen KE, Hatton TA. Liquid-liquid extraction of low-molecular-weight proteins by selective solubilization in reversed micelles. Sep Sci Technol 1987;22:831-41.

[29] Box GEP, Behnken DW. Some new three level desings for the study of quantitative variables. Technometrics 1960;2:455-75.

[30] Murtagh BA, Saunders MA. Large-sale linearly constrained optimization. Math Prog 1978;14:41-72.

[31] Lowry OH, Rosebrough NJ, Farr AC, Randall RJ. Protein measurement with the Folin phenol reagent. J Biol Chem 1951;193:265-75.

[32] Laemmli UK. Cleavage of structural proteins during the assembly the head of bacteriophage $\mathrm{T}_{4}$. Nature 1970;277:680-5.
[33] Imoto T, Yagishita K. A simple activity measurement of lysozyme. Agric Biol Chem 1971;35:1154-6.

[34] Dekker M, Riet H, Pol JJVD. Effect of temperature on the reversed micellar extraction of enzymes. Chem Eng J 1991;46:B69-74.

[35] Goklen KK, Hatton TA. Liquid-liquid extraction of low molecular-weight proteins by selective solubilization in reversed micelles. Sep Sci Technol 1987;22:831-41.

[36] Leodidis EB. Thermodynamics of solubilization in W/O droplet micro emulsions. Doctoral thesis. USA: Department of Chemical Engineering. Massachusetts Institute of Technology; 1990.

[37] Leser ME, Luisi PL. Application of reverse micelles for the extraction of amino acids and proteins. Chimia 1990;44:270-82.

[38] Wolbert RBG, Hilhorst R, Voskuilen G, Nachtegaal H, Dekker M, Van't Reit K, et al. The effect of protein size and charge distribution. Eur J Biochem 1989;184:627-33.

[39] Goklen KE, Hatton TA. Protein extraction using revere micelles. Biotechnol Prog 1985;1:69-74.

[40] Chang Q, Liu H, Chen J. Extraction of lysozyme, $\alpha$-chymotrypsin, and pepsin into reverse micelles formed using an anionic surfactant, isooctane, and water. Enzyme Micro Technol 1994;16:970-3.

[41] Naoe K, Shintaku Y, Mawatari Y, Kawagoe M. Novel function of guanidine hydrochloride in reverse micellar extraction of lysozyme from chicken egg white. Biotechnol Bioeng 1995;48:333-40.

[42] Lye GJ, Asenjo JA, Pylet DL. Extraction of lysozyme and ribonuclease using reverse micelles: limits to protein solubilization. Biotechnol Bioeng 1995;47:509-19.

[43] Nishiki T, Sato I, Kataoka T, Kato D. Partition behavior and enrichment of proteins with reversed micellar extraction: forward extraction of proteins from aqueous to reversed micellar phase. Biotechnol Bioeng 1993;42: 596-600.

[44] Krei G, Meyer U, Borner B, Hustedt H. Extraction of $\alpha$-amlyase using BDBAC-reversed micelles. Bioseparation 1995;5:175-83. 